\title{
Academic Writing: The Role of Culture, Language and Identity in Writing for Community
}

\author{
Sina Nasiri \\ Department of English, Urmia Branch, Islamic Azad Universiy, Urmia, Iran \\ Tel: 98-914-188-0479Ｅ-mail: sina.nasiri.86@gmail.com
}

Accepted: March 18, 2012 Published: May 02, 2012

Doi:10.5296/ijld.v2i3.1530ＵRL: http://dx.doi.org/10.5296/ijld.v2i3.1530

\begin{abstract}
When non-native scholars wish to write for their counterparts they should try to adapt their writing styles to the English norms which is considered as a national language among the global researchers around the world. Because the language they write is foreign, they face differences which make the writing difficult. These differences may be related to the different identity and cultural backgrounds. Accordingly, scholars should notice about the features of academic writing, in general and, in a particular field to overcome these differences. Therefore, the purpose of the present study is to give some enlightenment on the various elements which can have less or more effects on the style of non-native writers. Thus, this descriptive study makes clear the different features of the academic writing to help non-native writers to know some of the issues which should be pondered by writers in adapting themselves with the norms of writing which is acceptable by the English academic culture in a global scene. The findings give information to the EAP instructors to raise the learners' consciousness about the norms of the target culture.
\end{abstract}

Key words: Culture, Identity, language, Academic writing.

\section{Introduction}

In recent years, the separating of cultural, disciplinary and national barriers, especially in the context of academic and scientific writing has increased because of the globalization phenomenon. The process of globalization has certainly favored English, and in the last century English undoubtedly became the language of international communication in the academic and scientific contexts. Indeed, in several countries English has become the second or foreign language of many people who use it regularly, especially for their achievements. In addition, researchers who want to publish their findings in a particular field should consider the 
norms and standard factors of English in their writings. Considering the fact that researchers in one field may come from different countries, it is not bizarre to see that some of the misunderstandings and misconceptions of a specified matter happen. These happenings can be interpreted for the sake of differences in cultural norms and understandings. Therefore, they are possibly could continue in the writings of the researchers as academic writers.

What is considered as one of the barriers of the non-natives in English writing is the cross-cultural differences, since writers' language and cultural backgrounds may affect their writing (Clyne, 1987; Golebilowski, 1998; Mauranen, 1993; Martin, 2003; Moreno, 1997). Culture is a word which covers various areas in our life and, consequently, it has been defined by different authors in different ways. Hall (1969, p.20) defines culture as, "the way of life of a people. It is the sum of their learned behavior patterns, attitudes, and material things". He also considers culture not to be innate, but learned. Culture is a code we learn and share; this learning and sharing require communication (Smith, 1966). In a similar definition, Becher and Trowler (2001, p. 23) define culture as a set of "taken-for-granted values, attitudes and ways of behaving, which are articulated through and reinforced by recurrent practices among people in a given context".

According to these definitions it can be concluded that cultures have values for their members. Theses cultural values and beliefs are normally internalized through their socialization process (Eisenhart, 2001) and through interaction between individuals and their communities (Krause, Bochner \& Duchesne, 2003). Cultural values change slowly, they are not held to change like fashion. Values are supposed to endure over a long period of time. They give intensity, stability, direction, order and predictability to all aspects of one's life (Smith, 2000).

A number of studiers into cross-cultural differences between academic research articles (e.g. Canagarajah, 2002; Clyne, 1987; Duszak, 1997; Hyland, 2009; Lillis \& Curry, 2006; Ventola \& Mauranen, 1996) have pointed to the challenges non-native speakers, in particular, face when they learn how to write academically in a foreign language. According to these studies, problematic interferences from the $\mathrm{L} 1$ can occur on the different aspects of writing in a foreign language such as redundancy and repetition, misplacement of new information, being firm or tentative, textual organization, limited use of cohesive ties and argumentative strategies, lack of meta-discursive guidance, and etc. Therefore, knowledge of instructions of the appropriate patterns can help non-native writers to improve their writings in a way that their writings receive acceptance from the native ones.

Because of the different cultural and linguistic backgrounds, it is not uncommon to see the academic writers with different opinions and different construction of knowledge (Woodrow, 2006). As a result, these differences may become impediment for them to successfully meet the expectations of their communities. Academic writing in particular, due to lack of training and knowledge on academic writing, many researchers from non-English speaking backgrounds do not understand the expectations and requirements from their colleagues with regard to their written materials. In theory, academic writing has been discussed for many years, whereas, little empirical research has been conducted to discuss issues on academic writing in Iranian ESP and EAP contexts. Since researchers are the direct audience of their colleagues' writing, it is important to know what they think are the most important issues that writers need to pay particular attention to. 
Thus, some studies are required to analyze the texts written by natives in order to make clear the main characteristics of the academic texts written by writers whose culture is considered as the norm in academic and scientific writing.

When we analyze written texts, we analyze the language which belongs to the writer's identity. Since Language is a central feature of human identity. When we hear someone speak, we immediately make guesses about gender, education level, age, profession, and place of origin. Beyond this individual matter, a language is a powerful symbol of national and ethnic identity (Spolsky, 1999, p. 181). In other words, language of the authors, identity of the authors, and culture of the authors are inextricably intertwined. Neither identity nor language use is a fixed notion; both are dynamic, depending upon time and place (Norton, 1995). Considering the main idea of this study, it can be meant that, non-native writers can adapt themselves with the norms and conventions of the culture or discipline to which they write for.

As intercultural differences are bound to influence the comprehension of events in people belonging to different cultures, the non-native writers, when writing in English, are confronted with a psycho-cognitive situation where their native linguistic and cultural schemata conflict with the English schemata dominant in international professional communities, and therefore they are forced to negotiate and redefine their cultural identity in order to successfully communicate in international and intercultural settings. Because one should have enough knowledge of the standards of a particular setting if one wants to communicate successfully in that setting (Nasiri, 2011). Furthermore, anthropological and sociological accounts of cultural interaction in international communities and organizations (Hofstede 1991) suggest the possibility of hybrid communicative schemata in which a new set of cultural values and identities - functional to communication in the wider community - is created in response to the need to communicate internationally. The consequence is an inevitable move towards global communicative models. In this perspective, for the examination of written texts, genre analysis (Swales 1990, 2004; Bhatia 1993, 2004; Gillaerts \& Gotti 2005; Bhatia \& Gotti 2006) has proved to be particularly suited to identifying the discrepancies between global textual conventions and concrete realizations and has introduced new concepts such as genre mixing, repurposing or hybridization to account for generic dynamism.

\section{Features of Academic Writing of English Culture}

Regarding what was mentioned before, it is clear that the academic and scientific writings are dramatically influenced by the culture of the authors. It is also mentioned that English as a main language to make communication among the researchers around the world should be taken into account to help non-native writers on how to write for the global community. Therefore, the researcher of this study tries to look at and shortly explain the different features of the academic writing to help non-native writers in accommodating their writings with their native counterparts by considering the aspects which seems to be applied rightly in writing for the academic community. There are eight main features of academic writing, considered by the researcher's own view, that are often discussed. Academic writing is to some extent: complex, formal, objective, explicit, hedged, and responsible and it uses language precisely and accurately. These features are shortly described below. 


\subsection{Complexity}

Written language is relatively more complex than spoken language. Written language has longer words, it is lexically denser and it has a more varied vocabulary. It uses more noun-based phrases than verb-based phrases. Written texts are shorter and the language has more grammatical complexity, including more subordinate clauses and more passives. The more complex the structures of a text may probably show higher proficiency of the writers. In sum, according to Waskita (2008), complexity in academic writing is the means of integrating cited information, presenting statements, and organizing arguments.

\subsection{Formality}

Academic writing is relatively formal. In general this means that in a research article you should avoid colloquial words and expressions. In other words, certain styles of speaking and writing that may be perfectly acceptable in some mass media or other public contexts are not acceptable in the academic context. The work therefore needs to respect academic values and writing needs to adopt a certain formality of style. This style can be achieved through in-depth evaluation of the underlying features of the texts in a particular community or context. Since, Hyland claims that one of the ways of the representing the features of the underlying community is through metadiscourse.

\subsection{Precision}

In academic writing, facts and figures should be given in a way that no misunderstanding happens for the readers. Because the writer is not present while the readers read, the precision should be taken into account to compensate this shortage.

\subsection{Objectivity}

Written language is in general objective rather than personal. It therefore has fewer words that refer to the writer or the reader. This means that the main emphasis should be on the information that it aimed to be given and the arguments that are assumed to be make, rather than on the writer himself. For that reason, academic writing mostly uses passive voice and hence tends not to use 'I' and 'We'.

\subsection{Explicitness}

Academic writing is explicit about the relationships in the text. Furthermore, it is the responsibility of the writer in English to make it clear to the reader how the various parts of the text are related. These connections can be made explicit by the use of different signaling words. The cohesiveness of the texts should be done to guide the readers towards the gist by regarding the readers' expectations and backgrounds.

\subsection{Accuracy}

Academic writing uses vocabulary accurately. Most subjects have words with narrow specific meanings. Linguistics distinguishes clearly between 'phonetics' and 'phonemics'; general 
English does not. Therefore, each word should have accurate meaning in relation to the idea or subject it is used.

\subsection{Hedging}

Maybe the most important feature of the academic writing is the hedging devices. Hedging is a basic feature in academic discourse (Rounds, 1982) that enables academic writers to show their certainty and doubt towards their statements, to show the amount of confidence they put on their claim, and to start a dialog with their readers. Through using hedges, writers leave some room for their readers to judge the truth value of the assertion.

\subsection{Responsibility}

In academic writing, the writer must be responsible for, and must be able to provide evidence and justification for, any claims he makes. They are also responsible for demonstrating an understanding of any source texts you use.

\section{Summary and Conclusion}

Cross-cultural difference in thought and writing patterns has become a serious field of investigation only in the last twenty years or so. Accordingly, two opposing positions have emerged, one stressing the universality of academic discourse (Widdowson, 1979; Schwanzer, 1981), and the other postulating the culture-specificity of cognitive and textual structures (e.g. Kaplan 1966; Clyne, 1981, 1987, Galtung, 1985; House, 1997; Kachru, 1983).

Although it is often assumed that the discourse and rhetoric of texts are similar, the analysis of promotional texts (Lee, 2005) has shown that they are frequently characterized by differing features, since they are meant to serve readers of different social and educational backgrounds. Therefore, EAP (English for Academic Proposes) instructors should be aware of the cultural differences and try to proceed in their teaching in a way that the intercultural differences are minimized and students get familiar with the style of academic writing in the English culture. In the context of academia, discipline is one of the most important elements of the culture that define the professional lives of the members of the community. Disciplinary cultures influence the way in which academics approach their objects of study, report on their research activities, and interact with their colleagues (Becher \& Trowler 2001). Thus, the norms of the disciplinary cultures should be taught to the learners of that discipline to guide them step in a appropriate way.

As Kaplan (1966) claims, "different languages and cultures have different writing patterns". Sapir-Whorf hypothesis, which suggested by Edward Sapir and Benjamin Whorf, postulates that a particular language influences speakers' habitual thought. Different cultures shape different thoughts and perspectives to see the world, including different words and written discourse. Thus, a writer may have difficulty in learning composition of other countries if he has no idea about other cultures at all.

\section{Implication and suggestions for future studies}

What was explained in this study up to now, could give some noticing markers to the instructors of English for Specific Purposes (EAP). The discussed issues revealed that 


\section{Macrothink

instructors should be aware of the cultural differences and try to make them clear for their learners and find some ways to reach to the norms of specified field of study. Since each discipline has its own ways of representing information, the instructors at the first line and learners at the second line in educational contexts should try to find out the accepted rules in that particular setting and then try to adapt themselves with those rules. By doing so, they can feel free in writing for that setting because the intercultural differences reduces to the least amount and accordingly they can adapt the identity belonging to their field in the global community.

It is suggested that the prospective studies go through the details of each of the features and find out about the differences between the English culture and non-English cultures.

The careful design and accurate construction of these kinds of studies can strengthen the potential of the whole research area and enable the researchers to discover several aspects connected with the issues of lanaguage and identity in cross-cultural communication. 


\section{References}

Becher, T. \& Trowler, P. (2001). Academic tribes and territories: Intellectual enquiry and the culture of disciplines. Buckingham: Society for Research into Higher Education \& Open University Press.

Bhatia, V. K. (1993). Analysing genre: Language use in professional settings. London: Longman.

Bhatia, V. K. (2004). Worlds of written discourse: A genre-based View. London: Continuum.

Bhatia, V. K. \& Gotti, Maurizio (Eds) (2006). Explorations in specialized genres. Bern: Peter Lang.

Canagarajah, A. S. (2002). Multilingual writers and the academic community: Towards a critical relationship. Journal of English for Academic Purposes, 1 (1), 29-44

Clyne, M. (1981). Culture and discourse structure. Journal of Pragmatics, 5, 61-66.

Clyne, M. (1987). Discourse structures and discourse expectations: Implications for Anglo-German academic communication in English. In L. E. Smith (Ed.), Discourses across Cultures. Strategies in World English. New York: Prentice Hall.

Duszak, A. (Ed.) (1997). Culture and Styles of Academic Discourse. Berlin: Mouton de Gruyter.

Eisenhart, M. (2001). Changing conceptions of culture and ethnographic methodology: Recent thematic shifts and their implications for research on teaching. In V. Richardson (Ed.), Handbook of Research on Teaching (4th ed.) (pp. 209-225). Washington D. C.: American Educational Research Association.

Galtung, J. (1985). Structure, Culture and Intellectual Style. Social Science Formation , 20, 817-856.

Gillaerts, P. \& Gotti, M. (Eds) (2005). Genre variation in business letters. Bern: Peter Lang.

Golebiowski, Z. (1998). Rhetoric approaches to scientific writing: An English-Polish contrastive study. Text, 18(1), 67-102.

Hall, E. (1969). The hidden dimension. New York: Anchor Books.

Hofstede, G. (1991). Cultures and organizations. Software of the mind. London: McGraw-Hill.

House, J. (1997). Translation quality assessment: A model revisited. Tübingen, Narr.

Hyland, K. (2009) Academic Discourse: English in a global context. Continuum Discourse.

Kachru, Y. (1983). Linguistics and written discourse in particular languages: Contrastive studies: English and Hindi. Annual Review of Applied Linguistics, 3, 50-77.

Kaplan, R. B. (1966). Cultural thought patterns in intercultural education. In C. Kenneth (Ed.), Readings on English as a Second Language (pp. 399-418).Cambridge, Winthrop.

Krause, K., Bochner, S. \& Duchesne, S. (2003). Educational psychology for learning and teaching. Victoria: Thomson.

Lee, M. (2005). Uniqueness of Asian promotion discourse: A contrastive study of Hong Kong bilingual texts and native English texts. In Bargiela-Chiappini \& Gotti (Eds), 77-101. 
Lillis, T. \& Curry, M. J. (2006). Professional academic writing by multilingual scholars: Interactions with literacy brokers in the production of English-medium texts. Written Communication, 23 (1), 3-35.

Martin, M. P. (2003). A genre analysis of English and Spanish research papers abstracts in experimental social sciences. English for Specific Purposes, 22(1), 25-43.

Mauranen, A. (1993). Cultural differences in academic rhetoric: A textlinguistic study. Frankfurt am Main: Peter Lang.

Moreno, A. I. (1997). Genre constraints across languages: Causal metatext in Spanish and English RAs. English for Specific Purposes, 16(3), 161-179.

Nasiri, S. (2011). A contrastive study of hedges in environmental sciences RAs. Unpublished MA thesis. Urmia: IAU, Science and Research Branch, Department of English.

Norton, B. (1995). Social identity, investment, and language learning. TESOL Quarterly, 29(1), 9-31.

Rounds, P. (1982). Hedging in written academic discourse: Precision and flexibility. The University of Michigan, Mimeo.

Schwanzer, V. (1981). Syntaktisch-stilistische universalia in den wissenschaftlichen Fachsprachen. In T. Bungarten (Ed.) (1981) Wissenschaftssprache. Beiträge zur Methodologie, theoretischen Fundierung und Deskription (pp. 213-230). München, Fink.

Smith, A. G. (1966). Communication and culture: Readings in the codes of human interaction. New York: Holt Rinehart \& Winston.

Smith, M. J. (2000). Culture: Reinventing the Social Sciences. Buckingham: Open University Press.

Spolsky, B. (1999). Second-language learning. In J. Fishman (Ed.), Handbook of language and ethnic identity (pp. 181-192). Oxford: Oxford University Press.

Swales, J. (1990). Genre Analysis. Cambridge: Cambridge University Press.

Swales, J. (2004). Research genres: Explorations and applications. Cambridge: Cambridge University Press.

Ventola, E. \& Mauranen, A. (1996). Academic writing: Intercultural and textual issues. Amsterdam: John Benjamins.

Waskita, D. (2008). Differences in men's and women's ESL academic writing at the University of Melbourne. Jurnal Sosioteknologi Edisi, 14(7), 448-463.

Widdowson, H. G. (1979). Aspects of language teaching. Oxford, Oxford University Press.

Woodrow, L. (2006). English in academic settings: A postgraduate course for students from non-English speaking backgrounds. In M. A. Snow \& L. Kamhi-Stein (Eds.), Developing a new course for adult learners (pp. 197-218), Sydney: TESOL. 